\title{
Factors Affecting Learning Performance of Accounting Information System
}

\author{
Yung-Yu Lai \\ Department of Business Administration, Overseas Chinese University \\ No.100, Chiao Kwang Rd., Taichung, Taiwan R.O.C. \\ Tel: 886-92-819-5897_E-mail: caesar@ocu.edu.tw \\ An-An Chiu(Corresponding author) \\ Department of International Business, Feng Chia University \\ No. 100, Wenhwa Rd., Taichung, Taiwan R.O.C. \\ Tel: 886-910045312Ｅ-mail: ananchiu2009@gmail.com
}

Received: April 7, $2018 \quad$ Accepted: May 17, $2018 \quad$ Published: June 1, 2018

doi:10.5296/ajfa.v10i1.13039 URL: https://doi.org/10.5296/ajfa.v10i1.13039

\begin{abstract}
Due to the advancement of computer and information technology (IT), integrating the information and computing technology into the Accounting curriculum is one of the critical issues. This paper discusses whether the learning attitude towards information technology and the major in which these students enrolled will affect their respective learning performance based on testing results obtained from the questionnaire of the Accounting Information System Contest. Important findings include the following items: 1) Different learning attitude may affect the learning performance; 2) There is a significant difference in terms of the subjects of academic content and associated skills in the Contest for the participated candidates enrolled in different majors. From the results, it is notable that academic institutions should train instructors to help students develop better critical and creative skills required for pursuing their future profession and redesign the curriculum to integrate more relevant, practical skills in the emerging technology and Accounting knowledge areas. In addition, businesses should provide distinctive job training for employees from/with different education backgrounds to help them become more quickly adapted to the job.
\end{abstract}

Keywords: Accounting Information System, Information Technology (IT), Learning Attitude, Learning Performance 


\section{Introduction}

Nowadays, Information Technology (IT) tops the agenda of almost every college and university due to the predictions of and irresistible changes in a technologically advancing society (Milligan, 2010).Moreover, aggressive IT utilization is viewed as a vital sign of a progressive institution. These rapid IT advances have affected to all aspects of the business disciplines including the accounting profession. In specific, the influences of the nature of IT on accounting practices may push the entire accounting education profession to reform its system to be in concert with the dynamic, computing changes. Moreover, it is noted that computer skills have become the required skill for the practicing accountants (Bouchard, 2005; Kepczyk, 2005). To this end, the issue of integrating computer skills in accounting education has certainly been a continuing challenge and issue to discuss with professionals and educators (Jones and Abraham, 2007).

Although the application of information technology in assisting the learning outcome has proved to enhance the critical and creative thinking skill and develop a more global perspective (Speaker, 2004), many students in accounting failed to learn to apply the needed computer skills as fast as students in other disciplines. This is simply because the attitude that these students may have while using information technology is a vital aspect of their use of technology (Huffman et al., 2013).From the above discussion, the purpose of this paper is to investigate whether the learning attitude and the major in which these students enrolled will affect their learning performance of Accounting information systems. Most of the studies simply discussing the factors of influencing computer learning attitudes focused mainly on the subjects' background variables or the relationships of students' computer learning attitudes and their learning effectiveness. In specific, the subjects' background variables may include gender, department majors, availability of computer facilities, and computer experiences. However, there were few studies emphasized on the relationships of learners' learning attitudes and their learning motivation.

Accounting information is crucial for handling such tasks as decision making, record keeping, and discovery and prevention of theft. Business school students need to receive the adequate accounting training at schools such as financial reports analysis and this mainly because the financial report is vital to all businesses in every industry. Because of the development of information system technologies, the Accounting information systems (AIS)become indispensable in the business sectors. Accounting information system not only provides added value to improve the product quality and reduce the cost but also offer in-time and relevant information. One important aspect of today's workplace is that teams consist of a mosaic of interdisciplinary members with diverse functional areas as their primary responsibility. Such teams are now at the core of handling such task as how work is accomplished in today's corporations. Thus, students should learn how to function effectively as members of interdisciplinary teams. As technology continues to subvert various business models, the application of IT in all areas is no doubt the needed concept of/for cross-domain integration.

This paper analyzes the results by collecting questionnaires from the candidates participating in the Accounting Information System Contest to understand the key factors affecting 
learning performance in the areas of the information system. In total, 88 candidates participated in the Information Skill Contest in year 2010. Among them, 36 had an information technology education background and it only accounts for around $40.91 \%$. Surprisingly, this number stimulates the authors' curiosity whether the educational backgrounds of the participants (e.g., credits of accounting-related courses taken) make their learning performance different. Further, this paper is interested in investigating which type of students will perform better in AIS learning (e.g., those with an information technology background vs. those with an accounting background).Further, it is interesting to uncover which stage does the difference mainly result from if the students' performance does vary with various educational backgrounds? In other words, the authors want to locate these key factors in students' learning so as to enhance the learning performance for the area of accounting information systems in the future. It is the authors' attempt to uncover the complementary knowledge/skills needed to help these students with a prior information technology background and hence, assist them to actively learn the integrated AIS subject knowledge and hence achieve the best educational outcomes.

The result of this study could be useful and feasible for instructors in improving the learning quality of information systems courses, developing the corresponding curriculum, and understanding the key factors in improving the learning about the information system and related technologies. Targeting business-related departments including accounting, business management, international trade, and data processing provide a clearer understanding of the students' overall recognition and also provides a valuable opportunity to infer the insights for all students in a reasonable manner. It is expected that this study will provide information system learners without the sufficient relevant backgrounds with the key factors to be employed to overcome the educational difficulties and hence, improve their skills in adopting/utilizing the related systems. This study could also be used as an important guideline to enhance the learning effectiveness for students enrolled in accounting and/or information technology departments.

\section{Literature Review}

\subsection{Accounting information technology learning}

In the past few years, information technology has created a significant impact on business organizations. Knowledgeable and skilled users are critical to the successful implementation and for maximizing the benefits to utilize information technology. Consequently, universities and corporate training programs have incorporated learning information technology knowledge into the Accounting curriculum and conducted the required training. It has been suggested that digital tools, combined with appropriate pedagogy, may have been the potential to address some of the issues commonly associated with education (ter Vrugte et al., 2015). However, many authors propose that although the use of technology in classroom is increasing, the outcomes of its utilization do not live up to their perceived potential to enhance the learning experience

Research reveals that attitudes may form the foundations of one's beliefs which influence one's behaviors (Ajzen \& Fishbein, 2000). It further proves that there are significant 
relationships between attitudes and beliefs and between attitudes and behaviors. The positive attitude may create aninfluence on learning performance and learning motivation which are important for enhancing the learning outcome.If the students develop a positive attitude towards the use of computers in learning,they may try to make use of this technology often in learning and by doing so, it will make the learning process simpler and more effective. In the modern era, computer assists students to use/enhance their capability to assimilate, evaluate, and apply the available information. Workman (2005) suggests that users with a favorable attitude towards a specific technology are more likely to use that technology. Students' learning attitude affects the learning performance (Credé \& Kuncel, 2008).Learning attitude is one of the import factors affecting learning performance (Castillo-Merino, \& Serradell-López, 2014).

Students' academic achievement varies between public and private universities in Taiwan (Chen et al., 2010). For example, students enrolled in the public university are more active learners, such as asking teachers questions and discussing academic issues with peers, which contributes to a healthy learning culture and should therefore may create more impact on student academic achievement. In Taiwan, public universities differ from private universities in terms of faculty quality, student quality and resource acquisition. Not only do public universities have a higher percentage of faculty receiving a doctoral degree and a higher admission score requirement for incoming students, but they also have a better learning environment with more resources such as research facilities and computing support. In Taiwan, public universities enjoy a more prestigious status than their private counterparts. Students who studied in the public universities tended to use computers to fulfill more forms of various needs in their daily lives than their private university counterparts. Further, the students in public universities may perform better in the computing knowledge test than the students in private universities. Outstanding students with a good learning attitude prefer to choose the public university over the private university as their first choice in the admission or entrance exam. Taking the difference in students' quality into consideration, it is expected that there may exist a significant difference in their learning performance between the public and private university students in Accounting majors. As a result, this paper suggests that the learning performance of students in Accounting information system with different learning attitudes may be different.

Hypothesis 1: There is a significant difference between the learning attitude and learning performance of the Accounting information system.

Prior researches (He \& Freeman, 2010; Caputo, 2010) indicate that users' backgrounds such as major subject area may affect their learning attitude towards information technology. Students who major in science and technology area may possess a better information and computing literacy. In addition, respondents who have learned computing and information technology apparently have a lower anxiety than those who have no learning experience.

The participants are mainly from the following four business-related majors including accounting, business management, international trade, and data processing. All curriculums of four aforementioned majors teach the related information system courses. Further, it is 
noted that the contents of the courses offered by accounting department are more professional and specialized by its nature. On the other hand, the department of data processing may focus more on gaining a deeper insight and having more sophisticated manipulation of information technologies. From above discussion, this research assumes that students from different majors may perform differently in their learning performance.

Hypothesis 2: There is a significant relation between the major and learning performance of the Accounting information system.

\section{Research Methodology}

\subsection{Research Data}

Candidates may come from public and private vocational schools across the country. According to the statistics gathered by the Ministry of Education, 95 vocational schools had a business-related department in 2010. Of those 95 schools, 88 signed up for the skill contest, which accounted for $92.63 \%$. Our questionnaires covered almost all the vocational school students across the country. Further, the questionnaires were distributed to the candidates and their advisers at the point where the candidates completed their contest and in specific, they were actually collected right after the competition. In total, 38 questionnaires were received from 88 students, while 30 questionnaires were received from the advisors/instructors group who leads the same 88 students. The total of response questionnaires gathered was 68 , with a response rate of $38.6 \%$. A summary of the aforementioned statistics is shown in Table 1.

Table 1 . Summary of questionnaires collection

\begin{tabular}{cccc}
\hline Category & Number sent & $\begin{array}{c}\text { Number of } \\
\text { Responses }\end{array}$ & Response rate \\
\hline Students & 88 & 38 & $43.2 \%$ \\
Instructors & 88 & 30 & $34.1 \%$ \\
Total & 176 & 68 & $38.6 \%$ \\
\hline
\end{tabular}

In the contest, there are 40 multiple choice questions with 2.5 points each; additional penalty marks are not taken off for the wrong answers. The total points are 100, which accounts for $50 \%$ of the total results of the entire competition. The contest is conducted in the second day and it is mainly the computer-based test focusing on the skill subjects, which accounts for the remaining $50 \%$ of the total results. Candidates are asked to answer questions using the provided accounting information system example in the following order: (1) printing out the balance sheet before the company goes to a full computerization; (2) inputting entries and then printing out journals; (3) posting accounts and then printing out the general/subsidiary ledgers; and (4) printing out P\&L and balance sheet accordingly. The result of the skill subject is calculated by points, which are converted into a hundred-mark system. The accounting information systems example used in the competition contest is a stand-alone version and has the general ledger accounts and purchase/sales/inventory modules. Most students used "Beyond" software (82), others used "ES-AIS" software (4) and "e-GO" 
software (2) (Note 1), and all of these aforementioned software are not ERP systems.

\section{2 .Content of Questionnaire}

There are three accounting and information technology questions and namely, they include the following items:

1. Do you have a better understanding of practical accounting procedures after participating in this competition?

2. Can this competition contest enhance your knowledge and skills to apply the information technologies?

3. Do you understand better that the employed accounting information system example is implemented using a database system or software?

The answers provided in the questionnaire are measured on a five-point scale. Namely, 5 represents "strongly agree," 4 indicates "agree," 3 refers a "neutral," 2 means "disagree," and finally 1 stands for a "strongly disagree."In order to get the necessary information for a further analysis, the respondents were asked to provide the following demographic information such as school, gender, department, and status as a student or an adviser.

\section{Data Analysis Methods}

The purpose of accounting education is mainly to teach students the basic knowledge and professional techniques about accounting matters and thus provide the adequate training on related accounting skills to pursue the future career in this subject field. Accounting Information System Contest was first organized at Taiwan in 1954. This contest highlights the value to improve the vocational learning performance among different schools. Through a competition and observation of each other's performance, the contest, in fact, motivates the participating schools to strengthen the value of vocational education and thus, improve their students' learning in terms of specialized skills such as accounting.

Accounting Information System Contest is a competition associated with the integration of accounting and information technology knowledge and skills/capabilities. As noted earlier, students with a different learning background may have their own learning process about accounting and information technology knowledge. For example, students studying in the Department of Accounting may have a better understanding toward the accounting-related knowledge and skills while those studying in the Department of Data Processing or Information Technology may have a good knowledge in terms of the information and computing technologies. Consequently, there maybe some variation occurred from the different study areas, courses, and curriculum which may affect students' corresponding learning processes, and thus their learning outcomes. To discover the critical differences among the students from different departments and/or programs will certainly enhance the learning performance in this subject area. Moreover, by studying, understanding and then improving these potential problems identified, students from the Department of Data Processing or Information Technology can thus, maintain a balance and healthy integration of accounting and information technology knowledge and hence avoid the over-reliance on their 
operational skill of information technology to acquire, manipulate, and sometimes misuse the professional knowledge they need in the future career related to accounting information systems during their learning period. On the other hand, the students from the accounting department may also be able to learn more information system and technology knowledge even if they lack sufficient information system and technology background, prerequisite, and/or adequate capability which will affect the resulting learning performance in the area of AIS.

Respondents are categorized by either public school or private school groups to conduct the analysis. In addition, respondents are divided into four categories based on their majors including Business Management, International Trade, Accounting, and Data Processing. This research employs a one-way analysis of variance to analyze whether there is any difference among the aforementioned groups in terms of the academic performance. This study will next analyze each result in terms of the following items in terms of the skill subjects: "opening balance sheet,"“journals,"“general (subsidiary) ledger,"“profit and loss," and "closing balance sheet." Lastly, this study analyzes and discussed if there exists any difference in the total result.

With regard to information technology knowledge cognition, this research also divides the students into three groups according to the top, middle, and low achievement performance in terms of the academic background and skill subjects and then analyzes by using one-way ANOVA. Students and instructors/advisors are analyzed to understand if they have a similar recognition in terms of the information technology knowledge. F-test is employed to identify whether different results will lead to differences in recognition of skill contest and information technology knowledge.

\section{Empirical Analysis Results and Discussion}

The number of candidates participating in the skill contest in 2010 was 88 . The descriptive statistics results are presented in Table 2. The mean for these academic subjects is 45.085 and is transformed to 50.852after converting it into using a hundred-mark system. In addition, the lowest total score is 11 , while the highest one is 85 , and consequently, the average is 50.852 . Further, 45 of the research subjects came from public schools, which accounts for $51.1 \%$ of the total participants. 
Table 2. Descriptive statistics of participants' results

\begin{tabular}{|c|c|c|c|c|c|}
\hline & $\mathbf{N}$ & Minimum & Maximum & mean & $\begin{array}{l}\text { Standard } \\
\text { deviation }\end{array}$ \\
\hline Subject result & 88 & 10 & 73 & 45.085 & 13.199 \\
\hline $\begin{array}{l}\text { Opening balance } \\
\text { sheet }\end{array}$ & 88 & 0 & 23 & 20.932 & 5.177 \\
\hline Journals & 88 & 0 & 69 & 34.602 & 18.069 \\
\hline $\begin{array}{l}\text { General (Subsidiary) } \\
\text { ledger }\end{array}$ & 88 & 0 & 61 & 31.932 & 22.105 \\
\hline Profit and loss & 88 & 0 & 15 & 5.330 & 3.865 \\
\hline Closing Balance sheet & 88 & 0 & 21 & 10.250 & 5.102 \\
\hline $\begin{array}{l}\text { Total scores for skill } \\
\text { subjects }\end{array}$ & 88 & 0 & 182 & 103.045 & 45.535 \\
\hline Converted scores & 88 & 0 & 100 & 56.618 & 25.019 \\
\hline Total scores & 88 & 11 & 85 & 50.852 & 17.287 \\
\hline Public 1/private 0 & 88 & 0 & 1 & 0.511 & 0.503 \\
\hline
\end{tabular}

This research adopts Cronbach's $\alpha$ coefficient approach to verify reliability and measure the internal consistency. In general, if the coefficient $\alpha$ is greater, the reliability is higher. Further, $\alpha$ value which is greater than 0.7 means a very high reliability; a value between 0.5 and 0.7 is considered to be acceptable; and a value which is lower than 0.35 should be rejected. A structural reliability analysis is conducted on each factor, and Cronbach's $\alpha$ obtained is 0.836 . It is also noted that $\alpha$ coefficient of each factor is greater than 0.7 and thus it shows the good reliability.

The validity of this study is measured by using Pearson and Spearman coefficients as shown in Table 3. The following proposed questions are positively correlated and reach the significance level at 1\%. Namely, these questions include "You have a deeper understanding of the practical accounting procedures after participating in this competition;" "This competition can enhance the knowledge in the area of information technology;"“This competition can enhance the knowledge in understanding more information technology;" and "I understand accounting information system in this test is operated by a database system/software." As for the skill contest results, variables of each contest subjects are positively correlated and reach a significance level of $1 \%$. Namely, these variables are selected from the academic content such as opening balance sheet, journals, general (subsidiary) ledge, profit and loss, closing balance sheet and also included the following two items - total scores for skill subjects and total scores. 
Table 3. Pearson and Spearman correlation coefficient matrix

\begin{tabular}{|c|c|c|c|c|c|c|c|c|c|c|c|}
\hline & Q1 & Q2 & Q3 & $\begin{array}{l}\text { Subject } \\
\text { results }\end{array}$ & $\begin{array}{c}\text { Opening } \\
\text { balance } \\
\text { sheet }\end{array}$ & $\begin{array}{c}\text { Journal } \\
\text { s }\end{array}$ & $\begin{array}{l}\text { General } \\
\text { (Subsidiar } \\
\text { y) ledge }\end{array}$ & $\begin{array}{c}\text { Profit } \\
\text { and loss }\end{array}$ & $\begin{array}{c}\text { Closing } \\
\text { balance } \\
\text { sheet }\end{array}$ & $\begin{array}{c}\text { Total } \\
\text { scores } \\
\text { for skill } \\
\text { subjects } \\
\end{array}$ & $\begin{array}{l}\text { Total } \\
\text { scores }\end{array}$ \\
\hline Q1 & 1 & $0.357^{* *}$ & 0.071 & -0.112 & -0.130 & -0.199 & -0.084 & 0.093 & 0.078 & -0.102 & -0.092 \\
\hline$\overline{\mathrm{Q2}}$ & $0.390^{* *}$ & 1 & $0.403^{* *}$ & -0.195 & -0.073 & -0.133 & $-0.312^{* *}$ & -0.016 & 0.022 & -0.227 & -0.211 \\
\hline$\overline{\text { Q3 }}$ & -0.035 & $0.312^{* *}$ & 1 & 0.052 & 0.035 & 0.149 & -0.135 & 0.106 & 0.125 & 0.021 & 0.026 \\
\hline $\begin{array}{l}\text { Subject } \\
\text { results }\end{array}$ & -0.108 & -0.203 & 0.077 & 1 & $0.425^{* *}$ & $0.782^{* *}$ & $0.665^{* *}$ & $0.606^{* *}$ & $0.690^{* *}$ & $0.807^{* *}$ & $0.916^{* *}$ \\
\hline $\begin{array}{l}\text { Opening } \\
\text { balance sheet }\end{array}$ & -0.113 & -0.045 & -0.012 & $0.354^{* *}$ & 1 & $0.514^{* *}$ & $0.343^{* *}$ & $0.506^{* *}$ & $0.497^{* *}$ & $0.502^{* *}$ & $0.510^{* *}$ \\
\hline Journals & -0.197 & -0.187 & 0.136 & $0.757^{* *}$ & $0.435^{* *}$ & 1 & $0.712^{* *}$ & $0.635^{* *}$ & $0.763^{* *}$ & $0.891^{* *}$ & $0.898^{* *}$ \\
\hline $\begin{array}{l}\text { General } \\
\text { (Subsidiary) } \\
\text { ledge }\end{array}$ & -0.048 & $-0.334^{* *}$ & -0.083 & $0.646^{* *}$ & $0.366^{* *}$ & $0.667^{* *}$ & 1 & $0.529^{* *}$ & $0.605^{* *}$ & $0.914^{* *}$ & $0.849^{* *}$ \\
\hline $\begin{array}{l}\text { Profit and } \\
\text { loss } \\
\end{array}$ & 0.061 & -0.064 & 0.145 & $0.625^{* *}$ & $0.419^{* *}$ & $0.584^{* *}$ & $0.554^{* *}$ & 1 & $0.808^{* *}$ & $0.743^{* *}$ & $0.739^{* *}$ \\
\hline $\begin{array}{l}\text { Closing } \\
\text { balance sheet }\end{array}$ & 0.089 & -0.073 & 0.054 & $0.708^{* *}$ & $0.468^{* *}$ & $0.689^{* *}$ & $0.620^{* *}$ & $0.770^{* *}$ & 1 & $0.814^{* *}$ & $0.824^{* *}$ \\
\hline $\begin{array}{l}\text { Total scores } \\
\text { for skill } \\
\text { subjects }\end{array}$ & -0.098 & $-0.256^{*}$ & 0.033 & $0.785^{* *}$ & $0.526^{* *}$ & $0.895^{* *}$ & $0.906^{* *}$ & $0.716^{* *}$ & $0.798^{* *}$ & 1 & $0.967^{* *}$ \\
\hline Total scores & -0.107 & $-0.250^{*}$ & 0.052 & $0.911^{* *}$ & $0.488^{* *}$ & $0.890^{* *}$ & $0.854^{* *}$ & $0.719^{* *}$ & $0.807^{* *}$ & $0.971^{* *}$ & 1 \\
\hline
\end{tabular}

Remarks:1. Q1:You have a deeper understanding in practical accounting procedures after participating in this competition. 2. Q2:This competition can enhance the knowledge in understanding information technology. 3. Q3:I understand accounting information system provide in this test is operated by a database system or software. 4. Top right corner of the diagonal shows Spearman rank correlation coefficient and bottom left one shows Pearson product-moment correlation coefficient. 5. Figure in brackets represents the probability value $(P$-value) of two-tailed. ** means a significance level at $1 \%$. * means a significance level at $5 \%$.

Table 4presented below shows the results of academic knowledge and related IT skill contest for both public and private schools. In specific, 45 students are from public schools, while the other 43 students are from private schools. In terms of the academic knowledge results, the F-value obtained from one-way ANOVA is 2.325 and the p-value is 0.131 . These results indicate that no difference exists between the public and private schools. Further, this finding tends to justify the fact that students' educational backgrounds do not affect their performance in terms of academic subjects.

This research further analyzes the skill subject scores for each accounting subject matter. No difference is found in "Opening balance sheet" scores between public and private schools. However, the mean score of "starting from completing transaction entries and printing out journals" for the public-school students is 38.600.Consequently, this performance from the public schools is better than the results obtained from their counterparts (mean 30.419, $\mathrm{p}$ value 0.033 ). This difference between these aforementioned two groups (public vs. private schools) reaches a significant level.

The mean score of "General (subsidiary) ledger" for public school students is 36.244, which is also better than the mean of private school students (mean27.419, p-value0.061). The difference between these two aforementioned groups also reaches a significant level. 
Moreover, the mean score of "profit and loss" for public school students is 6.111, which surpasses the mean scores of private school students (mean4.512, p-value 0.052) and this difference also reaches a significant level. The mean of "total points for skill subject" from public school students is 113.133, which also surpasses the mean scores from private school students (mean92.488, p-value 0.033). This difference existed between two groups reaches also a significance level.

Finally, combining the results of both academic and skill subjects, the total mean score (with a $50 \%$ each for both academic subjects and skill subjects after converting them with a hundred-mark scale) for public school students is 54.664, which far exceeds the mean(46.862)of the private school students. Moreover, F-value from ANOVA is 4.667 and $\mathrm{P}$-value is 0.034; and this means that the result difference between the public and private schools is significant. The results of skill subjects are affected by the difference between students in public and private schools and this difference mainly comes from the capability of preparing journal entries.

Table 4. Analysis of difference between public and private schools' results in the Accounting Information System Contest

\begin{tabular}{|c|c|c|c|c|c|}
\hline Detail & Group & Number & Mean & F-test & Significance \\
\hline \multirow{2}{*}{ Subject results } & private & 43 & 42.907 & \multirow{2}{*}{2.325} & \multirow{2}{*}{0.131} \\
\hline & $\overline{\text { public }}$ & 45 & 47.167 & & \\
\hline \multirow{2}{*}{$\begin{array}{l}\text { Opening } \\
\text { sheet }\end{array}$} & private & 43 & 20.535 & \multirow{2}{*}{0.491} & \multirow{2}{*}{0.485} \\
\hline & public & 45 & 21.311 & & \\
\hline \multirow{2}{*}{ Journals } & private & 43 & 30.419 & \multirow{2}{*}{4.700} & \multirow{2}{*}{0.033} \\
\hline & public & 45 & 38.600 & & \\
\hline \multirow{2}{*}{$\begin{array}{l}\text { General (Subsidiary) } \\
\text { ledge }\end{array}$} & private & 43 & 27.419 & \multirow{2}{*}{3.611} & \multirow{2}{*}{0.061} \\
\hline & public & 45 & $\overline{36.244}$ & & \\
\hline \multirow{2}{*}{ Profit and loss } & private & 43 & 4.512 & \multirow{2}{*}{3.892} & \multirow{2}{*}{0.052} \\
\hline & public & 45 & 6.111 & & \\
\hline \multirow{2}{*}{ Closing balance sheet } & private & 43 & 9.605 & \multirow{2}{*}{1.351} & \multirow{2}{*}{0.248} \\
\hline & public & 45 & 10.867 & & \\
\hline \multirow{2}{*}{$\begin{array}{l}\text { Total scores for skill } \\
\text { subjects }\end{array}$} & private & 43 & 92.488 & \multirow{2}{*}{4.713} & \multirow{2}{*}{0.033} \\
\hline & public & 45 & 113.133 & & \\
\hline \multirow{2}{*}{$\begin{array}{l}\text { Total scores } \\
\text { (Skill subjects } \mathbf{5 0 \%} \text {, } \\
\text { academic subject50\%) }\end{array}$} & private & 43 & 46.862 & \multirow[b]{2}{*}{4.667} & \multirow[b]{2}{*}{0.034} \\
\hline & public & 45 & 54.664 & & \\
\hline
\end{tabular}

The skill contest part only involves some basic daily/routine operations of the AIS, such as opening accounts, daily transactions, and printing statements. As noted, completing accounting entries requires a higher specialized knowledge in accounting. This study finds out that the difference existed between the groups of public and private schools is in the 
category of "journals."The possible reason may be the different type of schools and the students' personality.

The difference of Students' academic achievement between public and private universities in Taiwan is huge. Students enrolled in the public university are usually more active learners than those in private university in many ways. For example, actively asking teachers questions and discussing academic issues with peers which make up for learning attitude, contribute to a healthy learning culture, and therefore may create more impact on the student academic achievement. Because of the huge difference in learning attitude, it is expected that there may exist a significant difference in their learning performance between the public and private university students. As a result, this paper suggests that the learning performance of students with different learning attitudes may be different.

As previously reported, there are in total 88 students participating in the Accounting Information System Contest. Two are excluded due to the insufficient and incomplete data. As a result, a total of 86 students is analyzed in this paper. Table 5 analyzes the performance of students with different major participated in the skill contest. In specific, 27 students major in Business Management, 13 students are from International Trade, 10 students with a major in Accounting, and finally, 36 students are in Data Processing area. Candidates from the Department of Data Processing have the highest ratio, which accounts for $41 \%$ of the total participants.

In terms of academic performance, the Department of Accounting obtained the highest scores (mean53.750), followed by the Department of International Trade (mean51.154) and the Department of Business Management(mean45.556), while the lowest one is the Department of Data Processing (mean 40.139). The F-value from one-way ANOVA is 3.368, while the $\mathrm{p}$-value is 0.013 . These results indicate that the difference existed among various majors may reach a significant level. In other words, it implies that students from different departments may have distinct differences in terms of their performance in the Accounting Information System Contest. In fact, students from the Department of Accounting excel in the academic subject. The major justification for this aforementioned fact could be their better understanding of accounting knowledge and also because of the fact that more accounting-related courses offered in their department.

In terms of skills results, there is no dramatic difference exists among different departments. The mean of "Journal" item is 48.000 in Department of Accounting, 43.154 in Department of International Trade,35.889 in Department of Business management, and finally 26.667inDepartment of Data Processing. The F-value from one-way ANOVA is 4.513 and the $\mathrm{p}$-value is 0.002 . Thus, the difference in journals task reaches a significant level. The possible reason may be that accounting activities are composed of a series of processes and the different practices/protocols may also exist in handling the following tasks such as subsidiary ledger, profit, and loss, closing balance sheet; and consequently, the total scores of skill subject may vary. The F-value obtained from one-way ANOVA is 5.031 and the p-value is 0.001 , which justify that there is a difference. It is obvious that students from Department of Accounting may perform better than those from Department of Data Processing. IT in 
education may encompass the complex processes to be engaged in by both individuals and organizations. Learning information technology is one of the ways to cultivate logical thinking and problem-solving ability. But there is a need for mastering interdisciplinary subject areas such as accounting and information technology to reinforce the employment of IT students. School can push students to build their own interdisciplinary pathway by choosing courses which make sense to them. As a result, having a double major or adding the additional minor in accounting since the goal of these IT-related departments is quite different in preparing the students' future career. 
Table 5. Analysis of differences among department's result in the Accounting Information System Contest

\begin{tabular}{|c|c|c|c|c|c|}
\hline & Major & Number & Mean & F-test & Significance \\
\hline \multirow{4}{*}{ Subject results } & Business management & 27 & 45.556 & \multirow{4}{*}{3.368} & \multirow{4}{*}{0.013} \\
\hline & International trade & 13 & 51.154 & & \\
\hline & Accounting & 10 & 53.750 & & \\
\hline & Data processing & 36 & 40.139 & & \\
\hline \multirow{4}{*}{$\begin{array}{l}\text { Opening balance } \\
\text { sheet }\end{array}$} & Business management & 27 & 21.444 & \multirow{4}{*}{0.569} & \multirow{4}{*}{0.686} \\
\hline & International trade & 13 & 20.692 & & \\
\hline & Accounting & 10 & 22.600 & & \\
\hline & Data processing & 36 & 20.111 & & \\
\hline \multirow{4}{*}{ Journals } & Business management & 27 & 35.889 & \multirow{4}{*}{4.513} & \multirow{4}{*}{0.002} \\
\hline & International trade & 13 & 43.154 & & \\
\hline & Accounting & 10 & 48.000 & & \\
\hline & Data processing & 36 & 26.667 & & \\
\hline \multirow{4}{*}{$\begin{array}{l}\text { General (Subsidiary) } \\
\text { ledge }\end{array}$} & Business management & 27 & 33.815 & \multirow{4}{*}{2.857} & \multirow{4}{*}{0.029} \\
\hline & International trade & 13 & 36.000 & & \\
\hline & Accounting & 10 & 47.500 & & \\
\hline & Data processing & 36 & 24.139 & & \\
\hline \multirow{4}{*}{ Profit and loss } & Business management & 27 & 5.259 & \multirow{4}{*}{3.154} & \multirow{4}{*}{0.018} \\
\hline & International trade & 13 & 6.769 & & \\
\hline & Accounting & 10 & 8.000 & & \\
\hline & Data processing & 36 & 4.000 & & \\
\hline \multirow{4}{*}{$\begin{array}{l}\text { Closing balance } \\
\text { sheet }\end{array}$} & Business management & 27 & 10.630 & \multirow{4}{*}{2.724} & \multirow{4}{*}{0.035} \\
\hline & International trade & 13 & 11.231 & & \\
\hline & Accounting & 10 & 13.800 & & \\
\hline & Data processing & 36 & 8.500 & & \\
\hline \multirow{5}{*}{$\begin{array}{l}\text { Total scores for skill } \\
\text { subjects }\end{array}$} & & & 107.037 & \multirow{5}{*}{4.382} & \multirow{5}{*}{0.003} \\
\hline & Business management & 27 & & & \\
\hline & International trade & 13 & 117.846 & & \\
\hline & Accounting & 10 & 139.900 & & \\
\hline & Data processing & 36 & 83.417 & & \\
\hline \multirow{4}{*}{ Total scores } & Business management & 27 & 52.184 & \multirow{4}{*}{5.031} & \multirow{4}{*}{0.001} \\
\hline & International trade & 13 & 57.952 & & \\
\hline & Accounting & 10 & 65.309 & & \\
\hline & Data processing & 36 & 42.986 & & \\
\hline
\end{tabular}

Table 6 below can be used to provide some additional details. In terms of the question- "Can this competition enhance the information technology knowledge?" the ANOVA results for students in the "low," "middle," and "high" categories do not reach the significant level. As for the advisors/instructors, the F-value is 6.021 and the p-value is 0.007 and these facts 
indicate that the significant level is reached. This finding implies that different groups will affect the recognition of enhancing the information technology knowledge. The mean score of the questionnaires answered by the low achievement students is 4.100 while the means of questionnaires answered by the middle and high achievement students are 3.800 and 3.000, respectively. Instructors/Advisors under the low achievement student category tend to agree with their group of students. However, it is interesting to note that the instructors of the high achievement students tend to be neutral. Furthermore, instructors with better performance results can deliver the adequate information technology knowledge to their students. Instructors assisting the Accounting Information System Contest will have a true understanding of the extent and subject content of information technology knowledge associated with the competition contest. Comparing with students, instructors may view this contest as a more useful tool to know students' ability to design the suitable course. For this reason, they can deliver and teach the relevant information to the candidates in a timely manner to avoid any misunderstandings in learning and also apply the needed information technology knowledge.

Table 6. Analysis of the students and instructors' recognition of information technology knowledge in the Accounting Information System Contest

\begin{tabular}{|c|c|c|c|c|c|c|}
\hline & Identity & Score & $\begin{array}{c}\text { Numbe } \\
\text { r }\end{array}$ & Mean & F-test & Significance \\
\hline \multirow{6}{*}{$\begin{array}{l}\text { 1. You have the deeper } \\
\text { understanding of practical } \\
\text { accounting procedures after } \\
\text { participating in this } \\
\text { competition }\end{array}$} & \multirow{3}{*}{ Student } & Low & 13 & 3.769 & \multirow{3}{*}{0.974} & \multirow{3}{*}{0.388} \\
\hline & & Middle & 12 & 3.250 & & \\
\hline & & High & 13 & 3.615 & & \\
\hline & \multirow{3}{*}{ Instructor } & Low & 10 & 3.600 & \multirow{3}{*}{1.136} & \multirow{3}{*}{0.336} \\
\hline & & Middle & 10 & 3.900 & & \\
\hline & & High & 10 & 3.300 & & \\
\hline \multirow{6}{*}{$\begin{array}{l}\text { 2. This competition can } \\
\text { enhance the knowledge in } \\
\text { information technology }\end{array}$} & \multirow{3}{*}{ Student } & Low & 13 & 3.769 & \multirow{3}{*}{0.107} & \multirow{3}{*}{0.899} \\
\hline & & Middle & 12 & 3.667 & & \\
\hline & & High & 13 & 3.615 & & \\
\hline & \multirow{3}{*}{ Instructor } & Low & 10 & 4.100 & \multirow{3}{*}{6.021} & \multirow{3}{*}{0.007} \\
\hline & & Middle & 10 & 3.800 & & \\
\hline & & High & 10 & 3.000 & & \\
\hline \multirow{6}{*}{$\begin{array}{l}\text { 3. I understand accounting } \\
\text { information system is operated } \\
\text { by the database system }\end{array}$} & \multirow{3}{*}{ Student } & Low & 13 & 3.615 & \multirow{3}{*}{0.664} & \multirow{3}{*}{0.521} \\
\hline & & Middle & 12 & 3.917 & & \\
\hline & & High & 13 & 3.923 & & \\
\hline & \multirow{3}{*}{ Instructor } & Low & 10 & 3.900 & \multirow{3}{*}{0.664} & \multirow{3}{*}{0.523} \\
\hline & & Middle & 10 & 3.900 & & \\
\hline & & High & 10 & 3.600 & & \\
\hline
\end{tabular}

\section{Conclusions and Future Implications}

Prior researches (Huang et al., 2014) about learning performance of information systems mainly focus on systems and/or applications such as e-mail, Internet, and word processing or 
the learning attitude mainly towards ERP adoption and/or implementation. In addition, most research (Zhang et al., 2013; He \& Yen, 2014)samples are rather limited to specific groups. There has been relatively little research and/or studies emphasizing the factors affecting learning performance of young students studying the subject of accounting information systems in the elementary level of the professional/vocational schools. These students, with the capability of handling accounting information systems related tasks, are the major resources as a professional accounting staff to enterprises in the future. By understanding the factors of learning performance for vocational school students, this paper expects to be served as a critical reference for educational institutions in the area of information system and accounting fields. Secondly, the findings of this paper can be utilized to improve some research gaps that exist in current teaching methods and pedagogies in IT area.

There are certain differences that may exist during some phases of the learning process of the information system education for students with various backgrounds. Instructors also have different recognition in terms of information technology, which will/may affect the learning results of their students. After an analysis, this study uncovers that the learning performance of students in private school is insufficient, because of their learning attitude. as a result, this finding indicates that students may have a poor performance from private schools than that of the students from public schools. Private school students shall strengthen their capability in the area of basic accounting in the future, which will further benefit their learning performance in the area of the information system by understanding the underlying accounting concepts.

As for the learning backgrounds of candidates, there is a significant difference among the associated departments in the school. Empirical results also show that different departments have a dramatic difference in terms of the coverage of the relevant academic and skill subjects. Students who performed the best are mainly from the Department of Accounting, Department of International Trade, Department of Business Management, and Department of Data Processing. Since the mean is lower than that of the average, coming from different departments may have a significant influence on the results. Students from departments that are outside of accounting should considerably strengthen the coverage in the relevant courses to improve their basic accounting knowledge. It is highly suggested that people who intend to work in an accounting information field start their learning from the basic accounting concepts instead of the skills of information technology in order to enhance their resulting learning performance and improve the competitiveness. After a further analysis, it is notable that the major reason for the difference is mainly their professionalism in accounting knowledge, not from the lack of skill in information technology. Furthermore, the results obtained in the skill contest do significantly affect the cognition of information technology.

This paper evaluates a student's learning performance using the fair and objective scores obtained in the skill contest organized by the government to analyze the possible obstacles to affect the learning in the accounting area. Accounting Information System Contest conducted every year is an important activity for continuously improving the relevant accounting curriculum of the vocational education in Taiwan. The organizing agents should review the exam questions strictly to guarantee the fairness of the contest, which is a critical component 
to encourage the students' participation, competition, and make future skills' improvements. In addition, how to integrate the IT knowledge and/or skills embedded in the accounting area and examine the content of the accounting courses offered by the vocational schools in different programs/departments and enhance the practices to improve the capabilities required in job market would be an important issue that deserves to be taken into account seriously by the educators in accounting and other related fields.

From the results, academic institutions should train instructors to help students develop critical thinking skills affecting the skill test results and most importantly required for their future profession and furthermore, to redesign the curriculum integrating more related practical/technological skill. Moreover, non-accounting major students should enrich their accounting profession and supplement accounting information system knowledge to achieve the best effect on learning. Businesses can also provide different on-job training for employees from different education backgrounds (e.g., those with an information technology background or those with an accounting background) to help their employees become more quickly adapted to the job.

\section{References}

Ajzen, I., \& Fishbein, M. (2000). Attitudes and the attitude-behavior relation: Reasoned and automatic processes. European Review of Social Psychology, 11(1), 1-33. https://doi.org/10.1080/14792779943000116

Bouchard, L. (2005). “Top Ten Trends in IT”, Gartner, Inc. http.www.gartner.com/accessed $8 / 5 / 2005$

Castillo-Merino, D., \& Serradell-López, E. (2014). An analysis of the determinants of students' performance in e-learning. Computers in Human Behavior, 30, 476-484. https://doi.org/10.1016/j.chb.2013.06.020

Caputo, D. (2010). Gender Differences In Assessing Essential Business Information Systems Technology Skills. International Journal of Management \& Information Systems, 14(2), $31-38$

Chen, C. B., Huang W. S., \& Chang W. C. (2010). Parental education methods, learning attitudes and perceptions of learning outcomes in higher vocational motor electronics group students. Journal of Education and Multicultural Studies, 2, 223-260.

Credé, M., \& Kuncel, N. R. (2008). Study habits, skills, and attitudes: The third pillar supporting collegiate academic performance. Perspectives on psychological science, 3(6), 425-453. https://doi.org/10.1111/j.1745-6924.2008.00089.x

He, J., \& Freeman, L.A. (2010). Are men more technology-oriented than women? The role of gender in the development of general computer self-efficacy of college students. Journal of Information Systems Education, 21(2), 203-212.

He, W., \& Yen, C. J. (2014). The role of delivery methods on the perceived learning performance and satisfaction of IT students in software programming courses. Journal of Information Systems Education, 25(1), 23

Huang, H. C., Davy, F. L., Shih, H. Y., \& Fan, C. J. (2014). Accelerating Knowledge Adoption: Information Systems Change Management. Approaches and Processes for 
Managing the Economics of Information Systems, 253. https://doi.org/10.4018/978-1-4666-4983-5.ch015

Huffman, A. H., Whetten, J., \& Huffman, W. H. (2013). Using technology in higher education: The influence of gender roles on technology self-efficacy. Computers in Human Behavior, 29(4), 1779-1786. https://doi.org/10.1016/j.chb.2013.02.012

Jones, G., \& Abraham, A. (2007). "Educational implications of the changing role ofaccountants Perceptions of practitioners, academics, and students", In The Quantitative analysis of teaching and learning in business, economics and commerce, Forum proceedings. Kepczyk, R. H. (2005). “The AICPA's Top Technologies for 2005”, The Trusted Professional: The Newspaper of the NYSSCPA http://www.nysscpa.org/trustedprof/405a/tp7.htm. (accessed 8/5/2005)

Milligan,W.W. (2010). Information Technology at Michigan Tech: 2010 Survey Results and Discussion. (Office of Information Technology, Michigan Technological University, Houghton, MI, USA.)

Speaker, K. (2004). Student perspectives: Expectations of multimedia technology ina college literature class. Reading Improvement, 41(4), 241-254

ter Vrugte, J., de Jong, T., Vandercruysse, S., Wouters, P., van Oostendorp, H., \& Elen, J. (2015). How competition and heterogeneous collaboration interact in prevocational game-based mathematics education. Computers \& Education, 89, 42e52. https://doi.org/10.1016/j.compedu.2015.08.010

Workman, M. (2005). Expert decision support system use, disuse, and misuse: a study using the theory of planned behavior. Computers in Human Behavior, 21(2), 211-231. https://doi.org/10.1016/j.chb.2004.03.011

Zhang, X., Zhang, C., Stafford, T. F., \& Zhang, P. (2013). Teaching introductory programming to IS students: The impact of teaching approaches on learning performance. Journal of Information Systems Education, 24(2), 147.

\section{Notes}

Note 1. The authors do not conduct variance analysis against software because most students used "Beyond" and there are too little samples in the other two. 